\title{
RANCANG BANGUN GAME TREASURE OF LABYRINTH DENGAN ALGORITMA BACKTRACKING BERBASIS ANDROID
}

\author{
Rio Andriyat Krisdiawan ${ }^{1}$, Ramdoni $^{2}$, Aji Permana ${ }^{3}$ \\ Fakultas Ilmu Komputer Universitas Kuningan \\ Jalan Tjut Nyak Dhien No. 36 A Cijoho Kuningan Jawa Barat 45513 Telepon (0232) 2875097 \\ rioandriyat@uniku.ac.id / rioandriyat@gmail.com,2015081090@uniku.ac.id,aji@uniku.ac.id
}

Game merupakan salah satu media hiburan yang menjadi pilihan hampir setiap orang untuk menghilangkan kejenuhan ataupun hanya mengisi waktu luang, ada juga game dijadikan hobi dan terlebih lagi game saat ini dijadikan olahraga elektronik (e-sport). Saat ini game memiliki banyak jenis permainan, salah satunya adalah jenis game teka teki (puzzle). Salah satu game teka-teki adalah game labirin. Labirin merupakan sebuah puzzle yang memiliki bentuk percabangan yang kompleks dan memiliki banyak jalan buntu. Pada saat ini banyak game yang berjenis labirin, akan tetapi masih jarang game labirin yang dilengkapi karakter, musuh dan sebuah arena labirin yang dinamis atau bisa berubah apabila permainan diulangi. Untuk membuat game labirin yang memiliki arena labirin yang dinamis diperlukan sebuah pembangkit labirin atau bisa disebut labyrinth generator dengan memanfaatkan algoritma backtracking. Algoritma ini cukup mangkus untuk digunakan dalam beberapa penyelesaian masalah dan juga untuk memberikan kecerdasan buatan dalam game. Metodologi perangkat lunak yang digunakan dalam pembuatan game yaitu GDLC (Game Development Life Cycle). GDLC adalah model pengembangan sebuah game yang menerapkan pendekatan iteratif yang terdiri dari 6 fase pengembangan, dimulai dari fase innitiation, pre-production, production, testing, beta dan realese. untuk pembangkitan arena labirin menggunakan algoritma Backtracking sedangkan untuk pengujian game ini menggunakan UAT (User Acceptment Test). Hasil penelitian ini berupa game petualangan berbasis teka-teki labirin yang diterapkan pada mobile android. Game ini dimainkan guna melatih pemain dalam pemecahan masalah dan sarana hiburan.

Kata Kunci : Game Puzzle, GDLC (Game Development Life Cycle), Algoritma Backtracking, UAT, Android

Games are one of the entertainment media which becomes a choice of almost everyone to get rid of boredom or just fill in spare time, there are also games used as hobbies and moreover games are now used as electronic sports (e-sports). Currently the game has many types, one of them is a type of puzzle game (puzzle). One of puzzle games is a maze game. The labyrinth is a puzzle that has a complex branching form and has many dead ends. At the moment there are many labyrinth type games, but there are rarely labyrinth games equipped with characters, enemies and a dynamic maze that can change if the game is repeated. To create a labyrinth game that has a dynamic labyrinth arena requires a labyrinth generator or it can be called a labyrinth generator by utilizing the backtracking algorithm. This algorithm is powerful enough to be used in some problem solving and also to provide artificial intelligence in the game. The software methodology used in making games is the GDLC (Game Development Life Cycle). GDLC is a game development model that adopts an iterative approach consisting of 6 development phases, starting from the innitiation, pre-production, production, testing, beta and realese phases. For the generation of the labyrinth arena, it uses the Backtracking algorithm while for testing this game uses the UAT (User Acceptment Test). The results of this study in the form of map puzzle based adventure game e that is applied to mobile android. This game is played to train players in problem solving and entertainment facilities.

Keywords: Puzzle Game, GDLC (Game Development Life Cycle), Backtracking Algorithm, UAT, Android

\section{PENDAHULUAN}

Perkembangan didunia Game saat

ini mengalami perkembangan yang sangat cepat terutama pada Game Android, dikarenakan perkembangan Smartphone Android saat ini semakin 
JURNAL NUANSA INFORMATIKA

Volume 14 Nomor 1, Januari 2020

canggih dan semakin banyak, seiring banyaknya pengguna Smartphone Android maka kebutuhan hiburan melalui media Smartphone Android semakin banyak terutama pada Game Android.

Game bergenre petualangan yang mengangkat unsur teka-teki yang bertemakan labyrinth/maze pada saat ini dikembangkan hanya sebatas menelusuri ruang atau jalan pada sebuah labirin untuk menemukan sebuah jalan keluar, tentu saja itu menjadi sebuah kekurangan karena hanya sebatas menelusuri sebuah labirin untuk menemukan jalan keluar saja, karena kurang adanya tantangan seperti adanya musuh pada permainan, contohnya seperti halnya pada permainan "Mine Maze" yang berbasiskan Android.

Dalam permainan "Mine Maze" tidak ada musuh dan tidak ada karakter jelas pada permainan tersebut, dan juga labyrinth pada game tersebut bersifat statis atau tidak berubah ketika permainan diulangi, sehingga ketika pemain memainkan permainan pada level yang sama maka permainan akan sangat mudah. Tentu saja hal ini mengurangi tantangan pada permainan tersebut, terlebih lagi tidak adanya musuh pada arena labyrinth pada permainan tersebut mengurangi tantangan dan unsur kesenangan pada game tersebut. Oleh karena itu penulis tertarik untuk mengembangkan game petualangan yang bertemakan labyrinth dengan penambahan karakter dan musuh beserta arena labyrinth yang dinamis yang selalu berubah ketika memulai permainan.

Untuk membangun sebuah labyrinth yang dinamis/dapat berubah setiap permainan dimulai tentu diperlukan sebuah sistem untuk membangkitkan sebuah labyrinth atau bisa disebut labyrinth generator. Salah satunya memanfaatkan algoritma
p-ISSN : 1858-3911, e-ISSN : 2614-5405

https://journal.uniku.ac.id/index.php/ilkom

backtracking. Algoritma ini cukup mangkus untuk digunakan dalam beberapa penyelesaian masalah dan juga untuk memberikan kecerdasan buatan dalam game.

Game yang akan dibangun bertujuan mengumpulkan harta karun dan mengalahkan musuh didalam sebuah arena labyrinth serta mencari jalan keluar sebagai goal pada setiap levelnya. Dengan adanya arena labyrinth yang dinamis serta musuh dan harta karun pada arena labyrinth akan membuat permainan menjadi lebih seru. Harta karung yang akan dibangun pada permainan ini bertemakan ciri khas Kabupaten Kuningan Jawa Barat, seperti senjata kujang, bokor, ikan dewa, batik dan yang terakhir adalah maskot kuningan yaitu patung kuda.

Berdasarkan uraian latar belakang masalah diatas, maka penulis dapat mengidentifikasi masalah yang perlu diatasi sebagai berikut:

1. Belum adanya Game yang berjudul Treasure of labyrinth berbasis android.

2. Belum adanya Game Treasure of labyrinth yang dilengkapi karakter, musuh dan harta karun bertemakan kearifan local kabupaten kuningan.

3. Tidak adanya karakter, musuh dan harta karun pada Game Mine Maze yang sudah ada di playstore.

4. Tidak adanya labyrinth generator pada Game Mine Maze.

Dalam melakukan penelitian ini penulis membatasi permasalahan agar aplikasi game yang dibangun sesuai dengan rencana dan spesifikasi yang ditentukan antara lain:

1. Game treasure of labyrinth yang dibangun dimainkan di sistem operasi android dan dapat dimainkan pada android minimal versi android kitkat.

2. Game treasure of labyrinth hanya dapat dimainkan oleh sigle player. 
JURNAL NUANSA INFORMATIKA

Volume 14 Nomor 1, Januari 2020

3. Game treasure of labyrinth ini hanya memiliki 5 tingkat kesulitan (Level).

a. Level 01, pemain disajikan sebuah labyrinth berukuran grig $5 \times 5$ dan musuh sebanyak 5, coin, kunci sebagai pembuka pintu pada jalan keluar sebagi goal dari permainan, item heal untuk menambah darah dari pemain dan harta karun.

b. Level 02, pemain disajikan sebuah labyrinth berukuran grig $7 \times 7$ dan musuh sebanyak 10 , coin, kunci sebagai pembuka pintu pada jalan keluar sebagi goal dari permainan, item heal untuk menambah darah dari pemain dan harta karun.

c. Level 03, pemain disajikan sebuah labyrinth berukuran grig 9x9 dan musuh sebanyak 15, coin, kunci sebagai pembuka pintu pada jalan keluar sebagi goal dari permainan, item heal untuk menambah darah dari pemain dan harta karun.

d. Level 04, pemain disajikan sebuah labyrinth berukuran grig $11 \times 11$ dan musuh sebanyak 20, coin, kunci sebagai pembuka pintu pada jalan keluar sebagi goal dari permainan, item heal untuk menambah darah dari pemain dan harta karun.

e. Level 05, pemain disajikan sebuah labyrinth berukuran grig $13 \times 13$ dan musuh sebanyak 25, coin, kunci sebagai pembuka pintu pada jalan keluar sebagi goal dari permainan, item heal untuk menambah darah dari pemain dan harta karun

4. Game engine yang digunakan untuk membangun aplikasi game treasure of labyrinth adlah UNITY.

5. Bahasa pemograman yang digunakan untuk membangun game treasure of labyrinth adalah $\mathrm{C \#}$.

6. Algoritma yang digunakan adalah algoritma Bacaktracking yang
p-ISSN : 1858-3911, e-ISSN : 2614-5405

https://journal.uniku.ac.id/index.php/ilkom

digunakan sebagai labyrinth

generator.

Adapun tujuan dari dilakukanya penelitian ini adalah sebagai berikut :

1. Untuk membangun game treasure of labyrinth berbasis android.

2. Untuk mengimplementasikan algoritma Backtracking pada game treasure of labyrinth sebagai labyrinth generator.

Manfaat dari dilakukannya penelitian ini adalah untuk memahami dan menerapkan model pengembangan GDLC dan algoritma Backtracking dalam mengembangun game treasure of labyrinth.

\section{METODELOGI PENELITIAN}

\subsection{Metodologi Pengembangan} Sistem

Metode pengembangan sistem yang digunakan dalam penelitian ini adalah metode Game Development Life Cycle (GDLC). GDLC adalah suatu proses pengembangan sebuah game yang menerapkan pendekatan iteratif yang terdiri dari 6 fase pengembangan, dimulai dari fase innitiation, preproduction, production, testing, beta dan realese.

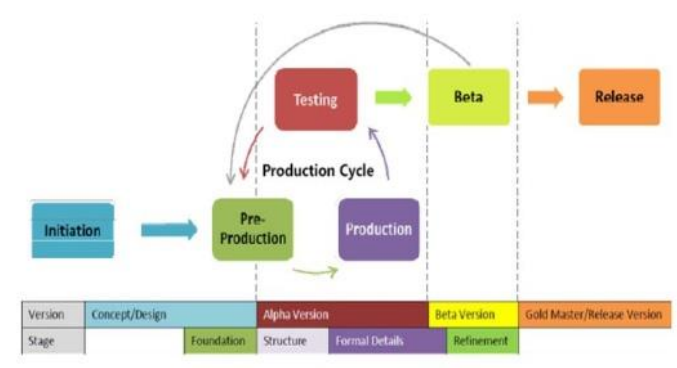

Gambar 1. Fase dan Proses GDLC Krisdiawan, R. A. (2018). Implementasi Model Pengembangan Sistem GDLC dan Algoritma Linear Congruential Generator pada Game Puzzle. NUANSA INFORMATIKA, 12(2). 
JURNAL NUANSA INFORMATIKA

Volume 14 Nomor 1, Januari 2020

Pada gambar fase dan proses GDLC menjelaskan bahwa GDLC memiliki 6 fase yang dapat dilakukan secara iteratif, yaitu tahapan Initiation, Ppreproduction, Testing, Beta serta Realease

\section{Initiation (Inisiasi)}

Penulis membuat sebuah konsep kasar dari game treasure of labyrinth yaitu berupa story berupa berpetualang disebuah labirin mencari jalan keluar serta mengumpulkan harta karun dan mengalahkan musuh yang ada pada arena labirin. Target pemain game yang penulis bangun adalah semua umur.

2. Pre-Production (Pra-Produksi)

Penulis membuat desain game berfokus pada mendefinisikan genre permainan, gameplay, game mekanik, alur cerita, tantangan dan faktor kesenangan

3. Production (Produksi)

Penulis membuat aset - aset game yang akan dibangun seperti Characther, Enemy, Item, Treasure, Desain UI, Music, Sound Effect, dan lainnya. Penulis juga memprogram game dan menyelesaikan game tersebut.

Asset Game :

Karakter : Karakter manusia dengan senjata. Hanya satu karakter dengan 3 kostum.

Enemy : Bermacam macam mosters Item : Senjata, darah, kunci, Harta karun : Koin emas, Harta karun kuningan.

4. Testing (Pengujian)

Penulis menguji fungsi fungsi serta fitur yang dibangun pada game apakah berfungsi dengan baik atau tidak, dengan menggunakan metode pengujian White Box dan Black Box. Ketika penulis mendapatkan bug atau kesalahan pada sistem penulis mendokumentasikan dan
p-ISSN : 1858-3911, e-ISSN : 2614-5405

https://journal.uniku.ac.id/index.php/ilkom

menganalisis bug tersebut dan memperbaikinya serta dilakukan analisis apakah sudah layak untuk masuk ke tahap selanjutnya yaitu Beta.

5. Pengujian Beta

Penulis melakukan pengujian yang melibatkan pihak eksternal untuk melakukan pengujian sistem yang disebut sebagai tester. Pengujian ini memiliki 2 jenis pengujian yaitu pengujian beta tertutup dan pengujian beta terbuka. Disini penulis menggunakan jenis pengujian beta tertutup, yaitu penulis melakukan pengujian dengan cara mengundang pihak individu yang memungkinkan untuk menjadi penguji. Tujuannya untuk mencoba sistem dan mencari bug yang terdapat pada sistem, jika penguji mendapatkan bug pada sistem maka akan dilakukan dokumentasi menggunakan metode UAT (User Accepment Test) untuk mendapatklan feddback dari penguji guna untuk menilai apakah game yang dibangun sudah layak untuk melanjutkan ke tahap selanjutnya yaitu realese.

6. Realese (Rilis)

Pengembangan sistem sudah mencapai tahap akhir dan siap untuk diliris ke publik. Untuk tahap ini penulis baru melakukan publish dengan menshare game tersebut secara itranet.

\subsection{Metode Pemecahan Masalah dengan Algoritma Backtracking}

Algoritma runut
(Backtracking)
diperkenalkan oleh D.H Lehmer
pada tahun 1950. Algoritma ini
cukup mangkus untuk digunakan
dalam beberapa penyelesaian
masalah dan juga untuk
memberikan kecerdasan buatan
dalam game. Beberapa game
populer semisal Sudoku, Labirin,


JURNAL NUANSA INFORMATIKA

Volume 14 Nomor 1, Januari 2020

Catur juga bisa diimplementasikan dengan menggunakan algoritma runut balik. Algoritma runut balik berbasis pada DFS (Depth First Search) sehingga aturan pencariannya akan mengikut kepada aturan pencarian DFS yaitu dengan mencari solusi dari akar ke daun (dalam pohon ruang solusi) dengan pencarian mendalam. Simpulsimpul yang sudah dilahirkan (diperiksa) dinamakan simpul hidup (live node). Simpul hidup yang sedang diperluas dinamakan simpul-E atau Expand Node.

Untuk menerapkan metode runut-balik, properti berikut didefinisikan:

1. Solusi persoalan. Solusi dinyatakan sebagai vektor $n$-tuple: $X=(x 1, x 2$, ..., xn), xi anggota himpunan berhingga Si Mungkin saja S1 = S2 $=\ldots=$ Sn. Contoh: $\mathrm{Si}=\{0,1\} \mathrm{Si}=0$ atau 11 . Fungsi pembangkit nilai xk Dinyatakan sebagai: $\mathrm{T}(\mathrm{k})$

$\mathrm{T}(\mathrm{k})$ membangkitkan nilai untuk $\mathrm{xk}$, yang merupakan komponen vektor solusi.

Fungsi Pembatas (fungsi kriteria) Dinyatakan sebagai: B(x1, x2, ..., xk) Fungsi pembatas menentukan apakah $(\mathrm{x} 1, \mathrm{x} 2, \ldots, \mathrm{xk})$ mengarah ke solusi. Jika ya, maka pembangkitan nilai untuk $x k+1$ dilanjutkan, tetapi jika tidak, maka (x1, x2, ..., xk) dibuang dan tidak dipertimbangkan lagi dalam pencarian solusi.

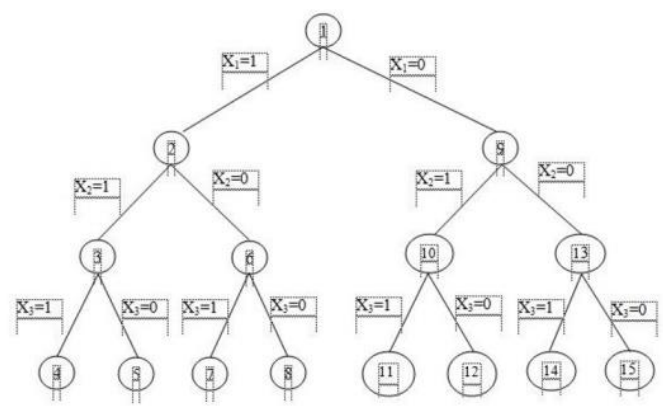

Gambar 2. Pohon Solusi (Bambang Fahrudin 2016).

Untuk flowchart proses pembangkitan arena labirin di lihat di gambar 3.

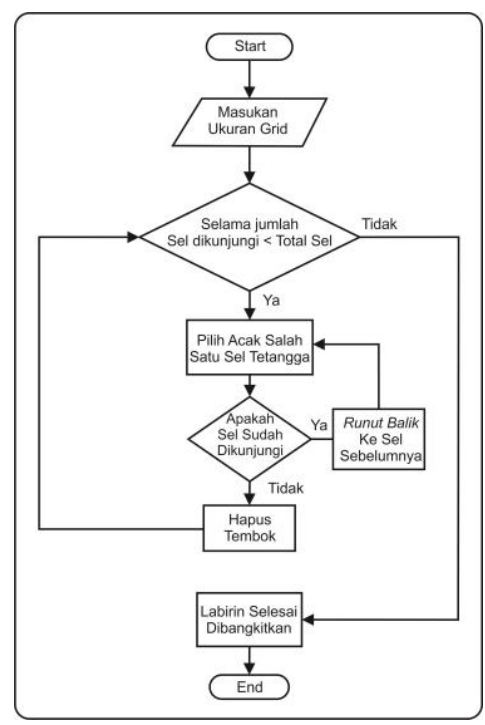

Gambar 3. Flowchart Sistem Proses Pembangkitan Labirin.

3. HASIL DAN PEMBAHASAN 3.1. Tahap Pre-Production (PraProduksi)

3.1.1. Sistem game yang diusulkan 
JURNAL NUANSA INFORMATIKA

Volume 14 Nomor 1, Januari 2020

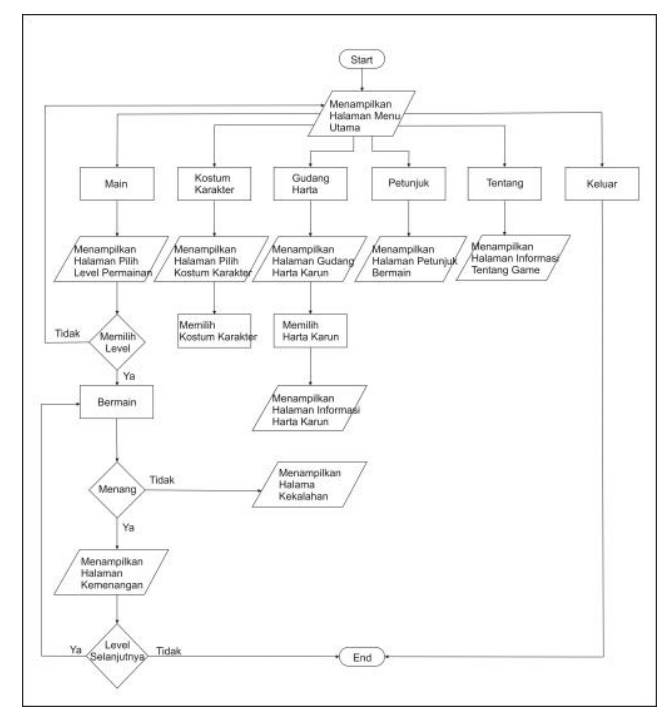

Gambar 4.Diagram Flow Menu Game 3.1.2. Story Board

Tabel 1. Story Board Scene 1

\begin{tabular}{|l|l|l|}
\hline \multicolumn{1}{|c|}{ Scene 1 } & $\begin{array}{c}\text { Memasuki area } \\
\text { labirin }\end{array}$ & $\begin{array}{c}\text { SScene } \\
1 / 5\end{array}$ \\
\hline & & \\
\hline
\end{tabular}

Tabel 2. Story Board Scene 2

\begin{tabular}{|l|l|l|}
\hline Scene 2 & $\begin{array}{l}\text { Mencari peti harta } \\
\text { karun }\end{array}$ & $\begin{array}{c}\text { SScene } \\
2 / 5\end{array}$ \\
\hline & \\
\hline Lokasi & $\begin{array}{l}\text { Didalam labirin } \\
\text { Aksi }\end{array}$ \\
\hline kan menemukan peti harta \\
\hline
\end{tabular}

Tabel 3. Story Board Scene 3

\begin{tabular}{|l|l|c|}
\hline Scene 3 & $\begin{array}{l}\text { Bertarung dengan } \\
\text { enemy }\end{array}$ & $\begin{array}{c}\text { SScene } \\
3 / 5\end{array}$ \\
\hline
\end{tabular}

p-ISSN : 1858-3911, e-ISSN : 2614-5405

https://journal.uniku.ac.id/index.php/ilkom

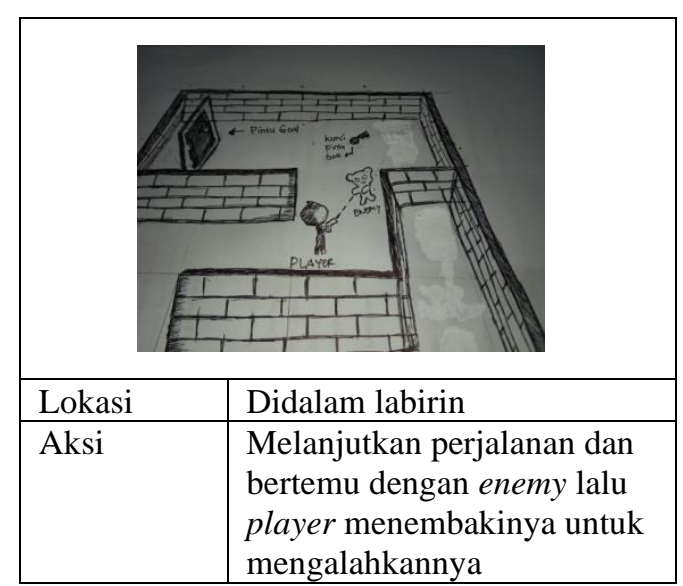

Tabel 4. Story Board Scene 4

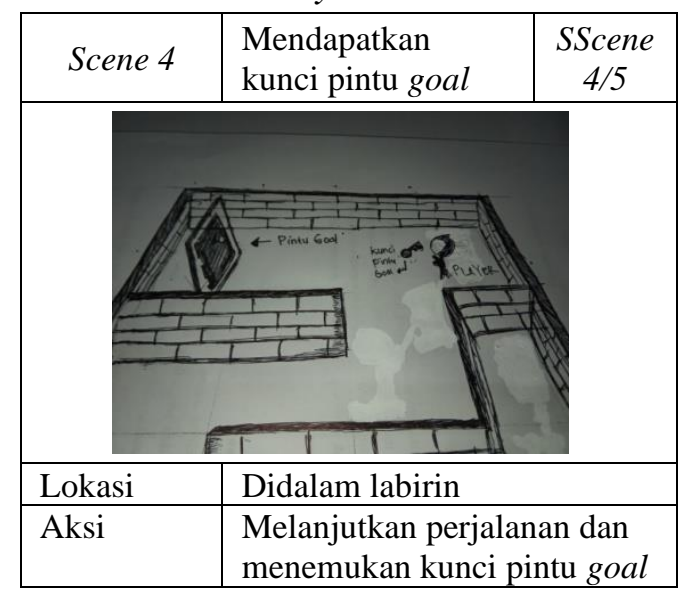

Tabel 5. Story Board Scene 5

\begin{tabular}{|l|l|l|}
\hline Scene 5 & Permainan selesai & $\begin{array}{c}\text { SScene } \\
5 / 5\end{array}$ \\
\hline Lokasi & Didalam labirin \\
\hline Aksi & $\begin{array}{l}\text { Player melanjutkan } \\
\text { perjalanan , dan dengan } \\
\text { didapatkannya kunci pintu } \\
\text { goal, player dapat } \\
\text { menyelesaikan permainan } \\
\text { dengan memasuki pintu goal. }\end{array}$ \\
\hline
\end{tabular}

\subsubsection{Perancangan Sistem Game Use Case Diagram}


JURNAL NUANSA INFORMATIKA

Volume 14 Nomor 1, Januari 2020

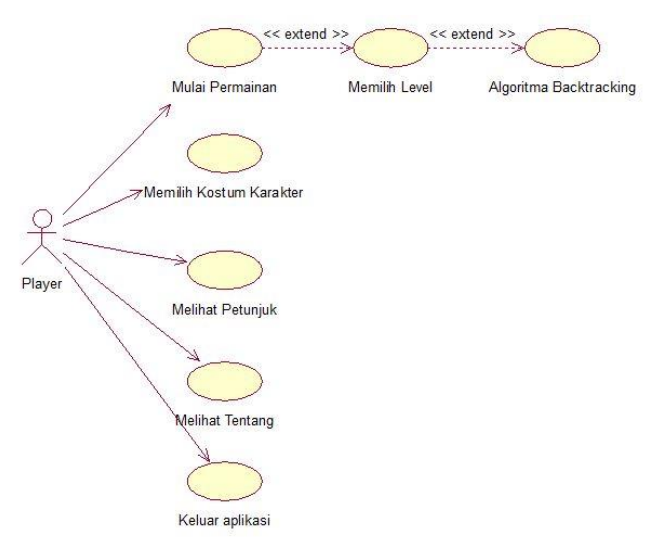

Gambar 5. Use Case Diagram Sistem Game Treasure Of Labirin.

\section{Activity Diagram Main}

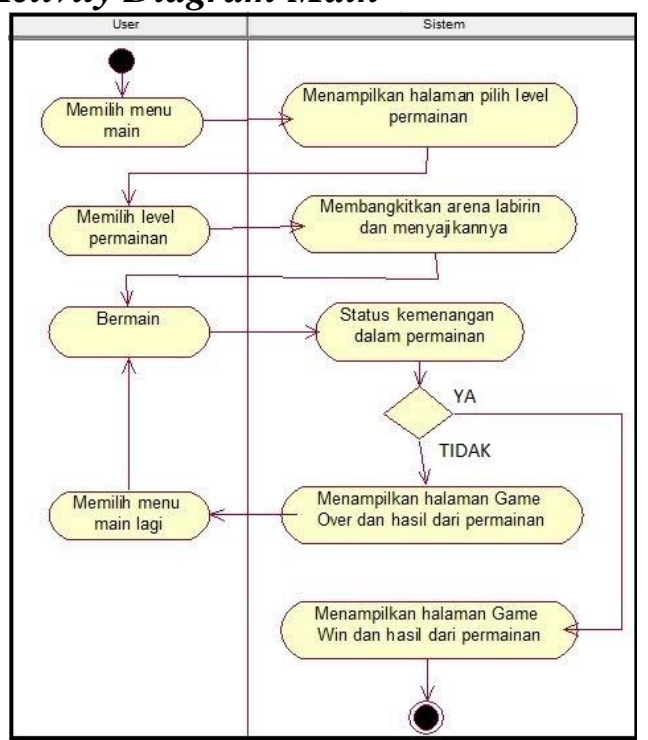

Gambar 6. Activity Diagram Main.

\section{Class Diagram}

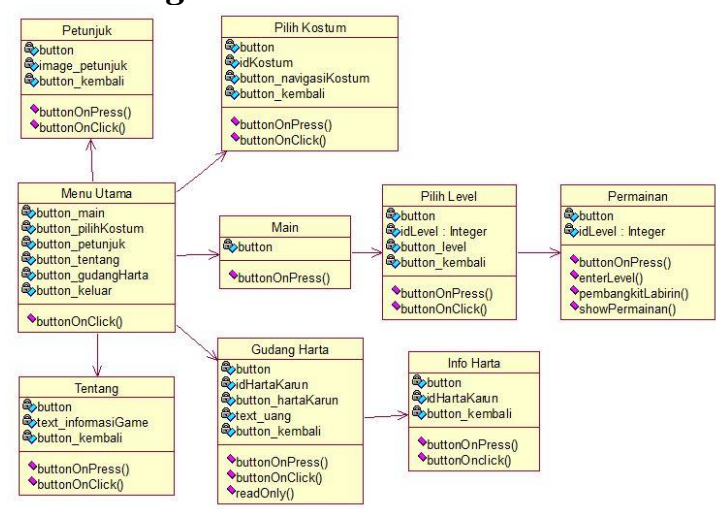

Gambar 7. Class Diagram Game Treasure Of Labyrinth.

\section{Sequence Diagram}

p-ISSN : 1858-3911, e-ISSN : 2614-5405

https://journal.uniku.ac.id/index.php/ilkom

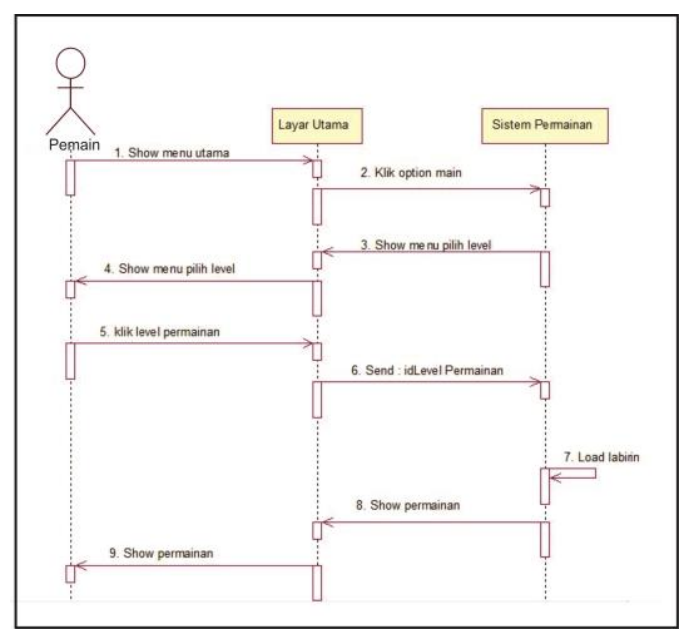

Gambar 8. Sequence Diagram Main

\subsection{Tahap Production}

Halaman Manu Utama

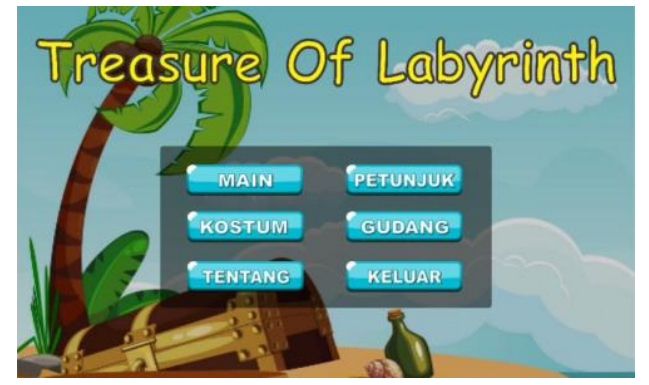

Gambar 9. Interface Halaman Utama Halaman Pilih Level

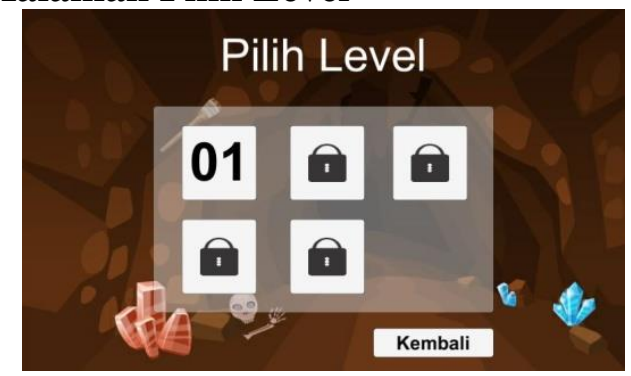

Gambar 10. Interface Halaman Pilih Level

Halaman Petunjuk

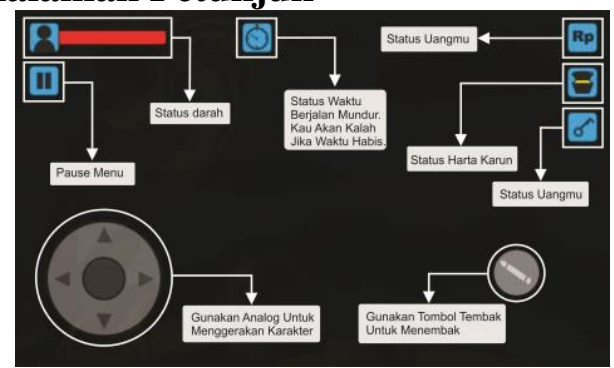

Gambar 11. Interface Halaman Petunjuk 


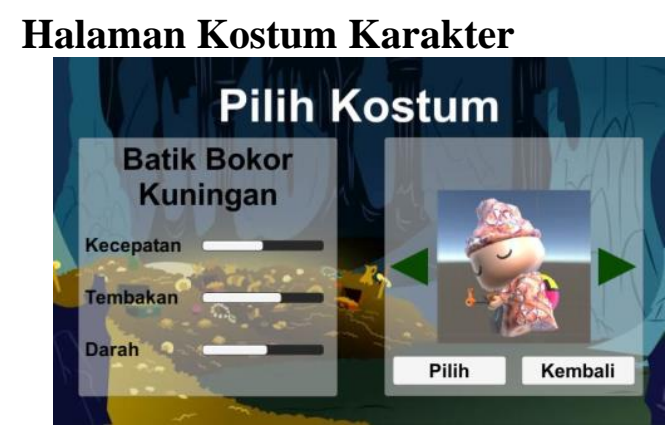

Gambar 12. Interface Pilih Kostum Karakter

Halaman Gudang Harta

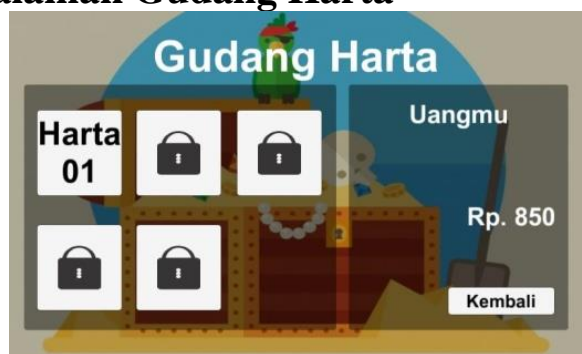

Gambar 13. Interface Gudang Harta

Halaman Info Harta Karun

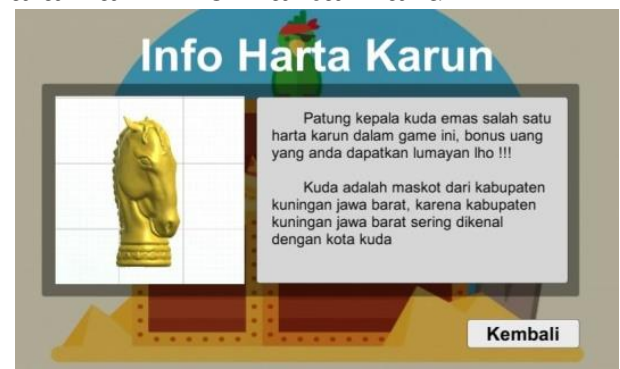

Gambar 14. Interface Halaman Info Harta Karun

\section{Halaman Permainan}

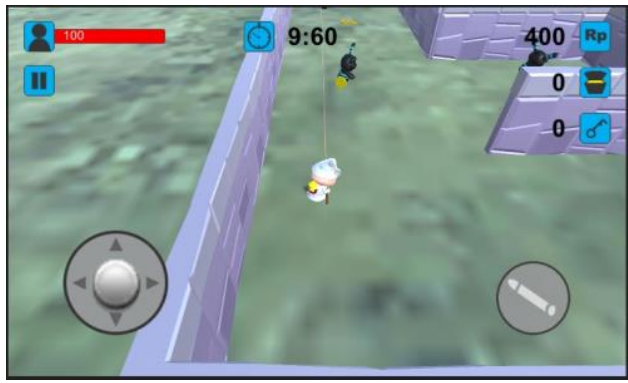

Gambar 15. Interface Halaman Permainan

\subsection{Tahap Testing}

PengujianBlack Box

Tabel 6. Pengujian Black Box Halaman Menu Utama

\begin{tabular}{|l|l|l|l|l|}
\hline \multicolumn{4}{|c|}{ Pengujiuan Black Box dari halaman menu utama } \\
\hline $\begin{array}{l}\text { Tomb } \\
\text { ol }\end{array}$ & $\begin{array}{l}\text { Aksi } \\
\text { Pemain }\end{array}$ & $\begin{array}{l}\text { Reksi } \\
\text { Siste } \\
\text { m }\end{array}$ & $\begin{array}{l}\text { St } \\
\text { at } \\
\text { us }\end{array}$ \\
\hline
\end{tabular}

p-ISSN : 1858-3911, e-ISSN : 2614-5405

https://journal.uniku.ac.id/index.php/ilkom

\begin{tabular}{|c|c|c|c|c|}
\hline $\begin{array}{l}\text { Menu } \\
\text { main }\end{array}$ & $\begin{array}{l}\text { Pemain } \\
\text { menekan } \\
\text { tombol } \\
\text { main }\end{array}$ & $\begin{array}{l}\text { Sistem } \\
\text { menampilk } \\
\text { an halaman } \\
\text { pilih level }\end{array}$ & $\begin{array}{l}\text { Sesuai } \\
\text { harapan }\end{array}$ & $\begin{array}{l}V \\
\text { ali } \\
d\end{array}$ \\
\hline $\begin{array}{l}\text { Menu } \\
\text { Petunj } \\
\text { uk }\end{array}$ & $\begin{array}{l}\text { Pemain } \\
\text { menekan } \\
\text { tombol } \\
\text { petunjuk }\end{array}$ & $\begin{array}{l}\text { Sistem } \\
\text { menampilk } \\
\text { an halaman } \\
\text { menu } \\
\text { petunjuk }\end{array}$ & $\begin{array}{l}\text { Sesuai } \\
\text { harapan }\end{array}$ & $\begin{array}{l}V \\
\text { ali } \\
d\end{array}$ \\
\hline $\begin{array}{l}\text { Menu } \\
\text { Kostu } \\
\text { m } \\
\text { Karak } \\
\text { ter }\end{array}$ & $\begin{array}{l}\text { Pemain } \\
\text { menekan } \\
\text { menu } \\
\text { kostum } \\
\text { karakter }\end{array}$ & $\begin{array}{l}\text { Sistem } \\
\text { menampilk } \\
\text { an halaman } \\
\text { menu pilih } \\
\text { kostum } \\
\text { karakter }\end{array}$ & $\begin{array}{l}\text { Sesuai } \\
\text { harapan }\end{array}$ & $\begin{array}{l}V \\
\text { ali } \\
d\end{array}$ \\
\hline $\begin{array}{l}\text { Menu } \\
\text { Gudan } \\
\text { g } \\
\text { Harta }\end{array}$ & $\begin{array}{l}\text { Pemain } \\
\text { menekan } \\
\text { tombol } \\
\text { gudang } \\
\text { harta }\end{array}$ & $\begin{array}{l}\text { Sistem } \\
\text { menampilk } \\
\text { an halaman } \\
\text { menu } \\
\text { gudang } \\
\text { harta }\end{array}$ & $\begin{array}{l}\text { Sesuai } \\
\text { harapan }\end{array}$ & $\begin{array}{l}V \\
\text { ali } \\
d\end{array}$ \\
\hline $\begin{array}{l}\text { Menu } \\
\text { Tenta } \\
\text { ng }\end{array}$ & $\begin{array}{l}\text { Pemain } \\
\text { menekan } \\
\text { tombol } \\
\text { tentang }\end{array}$ & $\begin{array}{l}\text { Sistem } \\
\text { menampilk } \\
\text { an halaman } \\
\text { tentang } \\
\text { aplikasi } \\
\text { game }\end{array}$ & $\begin{array}{l}\text { Sesuai } \\
\text { harapan }\end{array}$ & $\begin{array}{l}\text { V } \\
\text { ali } \\
d\end{array}$ \\
\hline $\begin{array}{l}\text { Menu } \\
\text { Kelua } \\
\mathrm{r}\end{array}$ & $\begin{array}{l}\text { Pemain } \\
\text { menekan } \\
\text { tombol } \\
\text { keluar }\end{array}$ & $\begin{array}{l}\text { Aplikasi } \\
\text { berhenti }\end{array}$ & $\begin{array}{l}\text { Sesuai } \\
\text { harapan }\end{array}$ & $\begin{array}{l} \\
\text { ali } \\
d\end{array}$ \\
\hline
\end{tabular}

\section{KESIMPULAN}

Dari penelitian yang yang telah di lakukan bahwa dengan menggunakan algoritma Backtracking pada game treasure of labyrinth untuk membangkitkan sebuah labyrinth yang dinamis, maka dapat di simpulkan bahwa:

1. Dengan memanfaatkan algoritma backtracking penulis dapat membangun sistem pembangkit labirin dynamis.

2. Model pengembangan $G D L C$ sangat cocok dalam membantu dalam membuat sebuah game.

3. Dengan dimasukannya icon-icon khas kabupaten kuningan sebagai harta karun dapat memperkenalkan sesuatu ciri khas dari kabupaten kuningan jawa barat. 
JURNAL NUANSA INFORMATIKA

Volume 14 Nomor 1, Januari 2020

\section{SARAN}

Game yang penulis kembangkan masih mempunyai beberapa kekurangan dan perlu adanya pengembangan kedepanya, maka dari itu penulis memiliki harapan dan saran dari hasil temuan peneliti diantaranya

1. Perlu adanya penambahan level dan karakter pada game sehingga permainan pada game akan lebih menantang.

2. Perlu adanya pengembangan game secara online untuk membuat sebuah permainan yang dapat dimainkan lebih dari 1 player disaat yang sama sehingga permainan dapat lebih menarik.

\section{DAFTAR PUSTAKA}

[1]. Andi Juansyah, (2015). "Pembangunan Aplikasi Child Tracker Berbasis Assisted-Global Positioning System (A-GPS) Dengan Platform Android”, Bandung : Jurnal Ilmiah Komputer dan Informaika (KOMPUTA).

[2]. Bambang Fahrudi, (2016). "Penerapan Algoritma Backtracking Pada Permainan Capsa Banting", Medan : Jurnal Riset Komputer (JURIKOM).

[3]. Gellysa Urva dan Helmi Fauzi S., (2015). "Pemodelan UML EMarketing Minyak Goreng", Sumatra Utara : Jurnal Teknologi dan Sistem Informasi.

[4]. Gun Gun M., (2017). "Pembelajaran Dasar Algoritma Dan Pem,ograman Menggunakan El-Goritma Berbasis Web", Bandung : Jurnal Teknik Mesin (JTM).

[5]. Hans Alfon E., Imam Kuswardayan dan Dr. Eng nanik S., (2016). "Rancang Bangun Game Berhitung Spaceship dengan Pengendalian Suara Menggunakan Speech
p-ISSN : 1858-3911, e-ISSN : 2614-5405

https://journal.uniku.ac.id/index.php/ilkom

Recognition Plugin pada Unity", Surabaya : Jurnal Teknik (ITS).

[6]. Jenifer Rori, Steven Sentinuwo dan Stanley Karouw, (2016). "Perancangan Aplikasi Panduan Belajar Pengenalan Ortodonsia Menggunakan Animasi 3D", Manado : E-Jurnal Teknik Informatika).

[7]. Lewis, W. E., (2009). Software Testing and Continuous Quality Improvement. ketiga ed. Boca Raton: CRC Press.

[8]. Nidhra, Srinivas dan Jagruthi Dondeti. (2012). Black box and White box Testing Techniques - A Literature Review. Internasional Journal of Embedded System and Applications (IJESA) Vol.2, No.2.

[9]. Krisdiawan, R. A. (2018). Implementasi Model Pengembangan Sistem GDLC dan Algoritma Linear Congruential Generator pada Game Puzzle. NUANSA INFORMATIKA, 12(2).

[10]. Rizky, Soetam. (2011). "Konsep Dasar Rekayasa Perangkat Lunak", Jakarta : Prestasi Pustaka, 2011.

[11]. Roger S. Pressman, (2002). Rekayasa Perangkat Lunak Pendekatan Praktisi (Buku Satu), ANDI Yogyakarta.

[12]. Suhendar, Andrianto, dan Gunadi, H. (2002). Visual Modelling menggunakan UML dan Rational Rose, Informatika Bandung, Bandung.

[13]. Wahyu Pratama, (2014). "Game Adventure Misteri Kotak Pandora", Purwokerto : Jurnal Telematika.

[14]. Wamiliana, Dian Kurniasari dan Dolly Yudhidtira, (2013). "Implementasi Aalgortima Backtrack untuk Pencarian Solusi Knight's Tour Problem pada Papan Catur", Lampung : Ilmu 
JURNAL NUANSA INFORMATIKA

Volume 14 Nomor 1, Januari 2020
p-ISSN : 1858-3911, e-ISSN : 2614-5405

https://journal.uniku.ac.id/index.php/ilkom

Komputer Unila Publishing

Network. 